\title{
Is the United Nations catching up with Ebola at last?
}

After the World Health Organization's much criticised delayed reaction to Ebola, the UN has sent in its big guns to tackle the outbreak. Nigel Hawkes and Sophie Arie report on the UN's first emergency health mission

\author{
Nigel Hawkes journalist, London, UK, Sophie Arie journalist, London, UK
}

Early in May, six weeks after the first case of Ebola virus disease had been confirmed in west Africa and rapidly spread into three of the poorest countries in the world, the director general of the World Health Organization, Margaret Chan, declared a public health emergency of international concern.

It is "an extraordinary event and a public health risk to other states for which a coordinated response is essential," she said. ${ }^{1}$

The health risk Chan was talking about was not from Ebola but polio-a disease for which only 413 cases were reported in the whole of 2013 (243 so far in 2014) and whose risk of spreading globally is low because of well established vaccination campaigns. What Chan feared was not the spread of polio but missing the target of eradicating polio by 2018 , which has been strongly urged on her by organisations such as the Gates Foundation and the US Centers for Disease Control and Prevention.

What she missed was a genuine global emergency that, according to WHO's figures, had already caused at least 160 deaths in three countries and whose spread had been described as "unprecedented" by the charity Médecins Sans Frontières (MSF). It took another three months, until 8 August, for Ebola to be declared a public health emergency: by then there had been 2274 cases in four countries and 961 people had died. The latest figures show that there have been a total of 13703 cases in the eight countries affected and 4922 deaths. $^{2}$

Public health specialists find it hard to understand WHO's delay. Joanne Liu, international director of MSF, says: "In the spring, WHO were downplaying it. We disagreed. We finally got the message across at the end of July. Margaret Chan told me: 'I don't want you to be pessimistic.' I said: 'I'm not being pessimistic_I'm just being realistic.'”

David Fidler, a law professor at Indiana University and an associate fellow at the Centre of Global Health Security at Chatham House, says: "I cannot make sense of what on earth went wrong. MSF and others were giving information that something very bad was going on with Ebola. Any time anybody mentions Ebola you get pins and needles. If WHO was getting this kind of information, its failure to act makes no sense.
"Their reactions were poor and mismanaged. Mistakes were made. WHO's credibility is badly damaged and that goes all the way from the operational level to the director general's office."

The United Nations has scurried to make up lost time, appointing one of its most experienced public health experts, David Nabarro, as senior coordinator for Ebola virus disease in August and setting up a UN Mission for Ebola Emergency Response (UNMEER), the first emergency health mission in the UN's history, under deputy Ebola coordinator Anthony Banbury.

On 12 October, Nabarro told the BBC that he believed a "reasonable target" would be to get the outbreaks under control within the next three months. ${ }^{3}$ By "under control" he explained that it meant that the numbers of new cases each week falling compared with the previous week, to the point where there was no new transmission. "All of us are going to have to perform in an outstanding way over some months," he said in an interview with the New York Times. ${ }^{4}$

\section{Has the beefed up UN response made a difference?}

Since he took on his role, Nabarro has placed emphasis on greater community involvement and understanding of the disease and how to avoid catching it. On 29 October, the UN reported the first signs that in Liberia, the country worst affected, the outbreak may have peaked. ${ }^{5}$ This is thought to be largely down to growing awareness and understanding of the disease and safer burial practices.

But as the numbers of cases continues to increase, albeit more slowly, those working on the ground remain concerned that the international effort still has a long way to go to catch up with and stamp out the virus.

Brice de le Vingne, director of operations for MSF, says the growing international effort has "reinforced the teams in the countries involved and brought in people with more managerial skills. But to be honest, there's little real increase in the number of beds. We're still far behind. 
"There is a new hospital in Liberia, that's good, and the International Federation of Red Cross and Red Crescent Societies has opened a treatment centre in Kenema in Sierra Leone, but so far as I know, that's it. So in terms of delivering the necessary quantity of isolation centres, we're still far behind."

Data from UNMEER suggests he has a point. On 23 October it said that only a quarter of the beds needed to achieve a target of isolating $70 \%$ of contacts by 1 December and $100 \%$ by 1 January 2015 are in place. For case identification it believes 28 laboratories are needed across the three countries; 12 are operational. Although 140 teams trained in the management of dead bodies are in place, another 230 are needed. ${ }^{6}$

De le Vingne also points the finger at the US and the UK. "The US army promised 17 centres, but nobody has been clearly appointed to run them," he says. So far, there is nothing for anybody to run, since none of the units is complete, despite President Obama stressing that time is of the essence. "The US also promised a 25 bed unit for health workers in Liberia, and it's still not functioning," de le Vingne says.

The same, he added, was true of the 62 bed facility the UK has undertaken to build in Freetown, Sierra Leone. To be fair to both governments, the undertakings were made on 8 September, and hospitals cannot be created overnight. Justine Greening, the UK international development secretary, promised that the unit would be operational within eight weeks. That target seems likely to be missed, but only by a few days.

Francesco Checchi, who is leading the Ebola response for Save the Children, has seen little sign of a change in the way the international effort is being managed since UNMEER was created. "The coordination battle has already been lost. At the time when this could have been stopped, there wasn't an agency coordinating. WHO just didn't step up to the plate.

"If you don't have coordination at the beginning, people start doing things on their own in silos. And then that's very hard to change. The result is that at the moment, we (the

non-governmental organisations on the ground) have no handle on who's doing what, where."

He added that the UN's latest timeline for increasing the numbers of treatment centres was "completely incommensurate with the way the virus is spreading."

\section{Why was the response so slow?}

The desperate rush to catch up with an outbreak that had a head start reopens the question of why it took so long for the world to react.

Fidler raises questions about WHO's priorities. "WHO has never been an expeditionary organisation," he says. "It's never had the resources to send fleets of public health specialists and doctors anywhere. Its job is on the front end-to identify something going on and getting on to it right away. That seems not to have happened here.

"Some people have blamed budget cuts, but if so that makes it worse. When you make strategic decisions about where to put the budget - within the secretariat or through the member states - and begin to take money out of the one area where you have the comparative advantage as a global organisation-communicable diseases surveillance and response-I get very angry because it undermines abilities WHO needs to have."

The leak of an internal WHO memo detailing the chronology of the Ebola outbreaks exposed deep anxieties within the organisation about its performance. ${ }^{7}$ It included an email from Bruce Aylward (who had been leading the polio eradication programme) to Chan, sent in June, saying that WHO's partners, including national health bodies and charities, believed WHO was "compromising rather than aiding" the response to Ebola. "None of the news about WHO's performance is good," the email said.

The internal report, leaked to Associated Press, said it was "particularly alarming" that the head of WHO's Guinea office refused to help get visas for an expert Ebola team and that $\$ 500$ 000 ( $£ 310000 ; € 400000$ ) had been blocked by administrative hurdles. WHO responded to the leak in a statement saying the document was "a first draft" that had not been fact checked and it would not comment further on it. It pledged "a full review and analysis of the outbreak" after it was over. ${ }^{8}$

Chan further defended her agency by arguing that it had faced simultaneous humanitarian crises in the Central African Republic, South Sudan, and Syria and two other disease outbreaks-Middle East respiratory syndrome and H7N9 flu—and "we are extremely stretched." Chris Dye, director of strategy at WHO, told The BMJ that nobody-not even MSF-had forecast the outbreak would get as bad as it has.

"We have to make a judgment about which health problems need major resources and attention," he said. "Many of these things we make a judgment on with limited resources, and sometimes we make the wrong decision.'

Robert Fortner, a US journalist and blogger and a long time critic of the influence of the Gates Foundation, believes that WHO was diverted from its prime purpose by Bill Gates's passionate advocacy of polio eradication, backed by the US representative to WHO, Nils Dulaire. ${ }^{10}$ It was Dulaire who at the end of January asked WHO's executive board to make polio a public health emergency, although what was at risk was a schedule, not actual lives. Dulaire set a deadline of the end of May, which was met.

In response to this, Fidler said: "If Gates is putting money into polio eradication, it's not as if he's forcing WHO to divert money. But the more money you have from outside bodies, the more it shifts the agenda. As well as Gates, we've had the Rockefeller Foundation pushing universal health coverage, and others have urged WHO to focus on non-communicable diseases and social determinants of health. If member states keep asking WHO to do everything, from obesity to Ebola and don't give it any money, then what do we expect?"

Competing interests: We have read and understood BMJ policy on declaration of interests and have no relevant interests to declare.

Provenance and peer review: Commissioned; not externally peer reviewed.

1 WHO statement on the meeting of the international health regulations emergency committee concerning the international spread of wild poliovirus, 5 May 2014. www. who. int/mediacentre/news/statements/2014/polio-20140505/en/.

2 WHO. Ebola response road map situation report, 29 October 2014. www.who.int./csr/ disease/ebola/situation-reports/en/.

3 Clarke T, Samb S. UN says $\$ 600$ million needed to tackle Ebola as deaths top 1900. Reuters 2014 Sep 4. www.reuters.com/article/2014/09/03/us-health-ebolaidUSKBNOGY1V320140903.

4 Fink S. With aid doctors gone, Ebola fight grows harder. New York Times 2014 Aug 18 www.nytimes.com/2014/08/17/world/africa/with-aid-doctors-gone-ebola-fight-grows-harder. $\mathrm{html}$ ? r $\mathrm{r}=0$.

5 Ebola crisis: infections "slowing in Liberia." BBC 2014 Oct 29. www.bbc.co.uk/news/worldafrica-29822303.

6 UN Office for the Coordination of Humanitarian Affairs. Ebola virus disease outbreak: overview of needs and requirements. 2014. www.unocha.org/cap/appeals/ebola-virusdisease-outbreak-overview-needs-and-requirements-september-2014.

7 UNMEER. External situation report, 23 October 2014. www.un.org/ebolaresponse/pdf/ Situation Report-Ebola-23Oct14.pdf.

8 Masters S. WHO missed the disaster of our times." Independent on Sunday 2014 Oct 19. www.independent.co.uk/life-style/health-and-families/health-news/ebola-outbreakwho-missed-the-disaster-of-our-times-say-aid-agencies-9804285.html. 


\section{What is needed for an effective response?}

David Nabarro, the British public health specialist handed the task of playing catch-up to the Ebola virus, has the perfect cv for the job. He's worked as a district child health officer in Nepal, a regional manager for Save the Children Fund, an academic in London and Liverpool, an adviser to the UK government, a project manager for WHO, and avian flu supremo for the UN secretary general.

His role is to provide strategic leadership, coordination, and guidance, while Anthony Banbury, an American citizen who has worked for the UN and the US government, is in charge of operational matters, directing the UN Mission for Ebola Emergency Response. This body draws its staff of 96 from the diverse agencies of the UN together with experts from several countries.

Nabarro began his role by banging the drum for a wholehearted international response. He estimated on 4 September that if the outbreak was to be stopped, it would take at least $\$ 600 \mathrm{~m}$ and require "several thousand people to scale up our response by three to four times."11

A more detailed analysis by the UN Office for the Coordination of Humanitarian Affairs on 16 September put the total at $\$ 987.8 \mathrm{~m}$, which includes $\$ 189.5 \mathrm{~m}$ for identifying and tracing people with Ebola infection, $\$ 331.2 \mathrm{~m}$ for caring for them, and more than $\$ 100 \mathrm{~m}$ for food security and nutrition. ${ }^{12}$ Most of this money, more than $\$ 600 \mathrm{~m}$, needs to be spent in Liberia, the country with the greatest number of cases, with Guinea and Sierra Leone splitting the rest.

Commitments to the UN secretary general's trust fund for Ebola started slowly-there was just $\$ 100000$ in the pot a month after launch. But it has picked up since, and by 29 October $\$ 116 \mathrm{~m}$ had been pledged. However, only $\$ 13.5 \mathrm{~m}$ had actually been transferred from donors. ${ }^{13}$ Meanwhile, some organisations and countries are spending large sums independently of the UN. The World Bank, whose president Jim Yong Kim is an infectious disease specialist, has promised $\$ 400 \mathrm{~m}$, disbursing more than $\$ 100 \mathrm{~m}$ quickly for immediate needs. The organisation, which has a remit to support the global economy and normally invests in infrastructure and development projects, has never previously funded an emergency health project. The UK has committed more than $£ 200 m$, focusing mainly on Sierra Leone and including a £20m contribution to the secretary general's fund. The US has committed $\$ 350 \mathrm{~m}$ and made a major commitment for the US Department of Defense which may exceed $\$ 1 \mathrm{bn}$.

9 WHO. WHO response to internal Ebola document leaked to media. Press release, 18 October 2014. www.who.int/mediacentre/news/statements/2014/ebola_document_leak en/.

10 Chan M. WHO press conference, 8 August 2014. www.who.int/mediacentre/multimedia/ 2014/who-ebola-outbreak-08aug2014.pdf?ua=1.

11 Fortner R. Polio: what the "other" global health crisis tells us about Ebola, 23 October 2014. http://robertfortner.posthaven.com/polio-what-the-other-global-health-crisis-tellsus-about-ebola.
12 UN. Trust fund factsheet, 29 October 2014. http://mptf.undp.org/factsheet/fund/EBO00. 13 UN: Ebola outbreak could be controlled in three months. BBC 2014 Oct 12. www.bbc. co.uk/news/world-africa-29586629.

Cite this as: BMJ 2014;349:g6576

(c) BMJ Publishing Group Ltd 2014 